\title{
Influence of benthic macroinvertebrates on mixing of profundal sediments in southeastern Lake Huron ${ }^{1}$
}

\begin{abstract}
Vertical distributions of size classed benthic macroinvertebrates were investigated in centimeter-thick sections of twelve cores from each of two stations in southern I ake Huron. Stations were selected on the basis of radioactivity profiles indicating surface sediment mixing to 3 and $6 \mathrm{~cm}$. The corresponding occurrence of major taxonomic groups (amphipods and oligochaetes) to $2 \mathrm{~cm}$ at the first station and to $4 \mathrm{~cm}$ at the second suggests that these organisms play a significant role in sediment redistribution. Comparison of published tubificid defecation rates with sedimentation rates determined radiometrically indicates the extent to which benthic macroinvertebrates can mix surficial sediments.
\end{abstract}

Profiles of natural and artificial radioactivity in recent sediments of the Great Lakes suggest that postdepositional movement of material occurs within the upper $10 \mathrm{~cm}$ of sediments (Robbins and Edgington 1975). Robbins and Edgington (1975) and Robbins et al. (1977) have proposed that the observed redistribution of sediment particles and their strongly sorbed radionuclides results from either physical mixing (resuspension) or bioturbation. Larger benthic invertebrates mix both lacustrine and marine sediments (Davis 1967, 1974a,b; Rhoads 1963, 1974). But the vertical distribution of deposit feeders in profundal sediments of the Great Lakes and the factors which determine their vertical distribution remain largely uninvestigated.

We measured the vertical distribution of benthic macroinvertebrates at two stations in Lake Huron (Table 1), selected on the basis of differing thicknesses of the mixed layer determined radiometrically, to see whether densities of benthos at these stations were sufficient to ac-

\footnotetext{
${ }^{1}$ This research was supported by EPA grant R803086 to C. L. Schelske, Great Lakes Research Division, and constitutes part of a M.S. degree by J. R. K. Contribution 230 of the Great Lakes Research Division, University of Michigan.
}

count for the rate of mixing implied by the radioactivity data. We collected our samples with a Benthos gravity corer having a butyrate-plastic liner (area, 35.5 $\mathrm{cm}^{2}$ ), during August 1975, in an extensive area of fine-grained recent deposits in southeastern Lake Huron (Goderich Basin: Thomas et al. 1973). We lowered the corer without core cutter or retainer at $\sim 1$ $\mathrm{m} \cdot \mathrm{s}^{-1}$ (less than free-fall velocity) to limit disturbance of the surficial sediments (Flannagan 1970; Milbrink 1973). Our ship did not anchor during sampling but maneuvered on station between casts. On-deck observations of intact chironomid tubes at the mud-water interface within the core liner offered strong evidence of limited sediment disturbance by the corer; however, we must agree with Milbrink (1973) that little can be done to prevent animals from moving in response to the shock of the corer entering the sediments. Our coring procedure smeared a small percentage of sediment and benthos along the inside surface of the tube, especially since no piston was used, and our subsequent handling of the cores during sectioning may have altered the in situ distribution. We believe that these components of the observed vertical distribution are probably not great enough to invalidate our results, however, since we found the greatest densities of organisms within the uppermost 6 cm of sediment (Fig. 1), as did Brinkhurst et al. (1969) and Milbrink (1973) using different sampling devices.

We determined sample size (twelve cores per station) following Elliott's (1971) index of precision and using earlier data (S. C. Mozley unpubl.) on populations collected from cores of Lake Michigan sediments.

At station 14, which is centered in the northern area of Goderich Basin, the sediments consist of brown, flocculent material in the upper $4 \mathrm{~cm}$, overlying firm, 


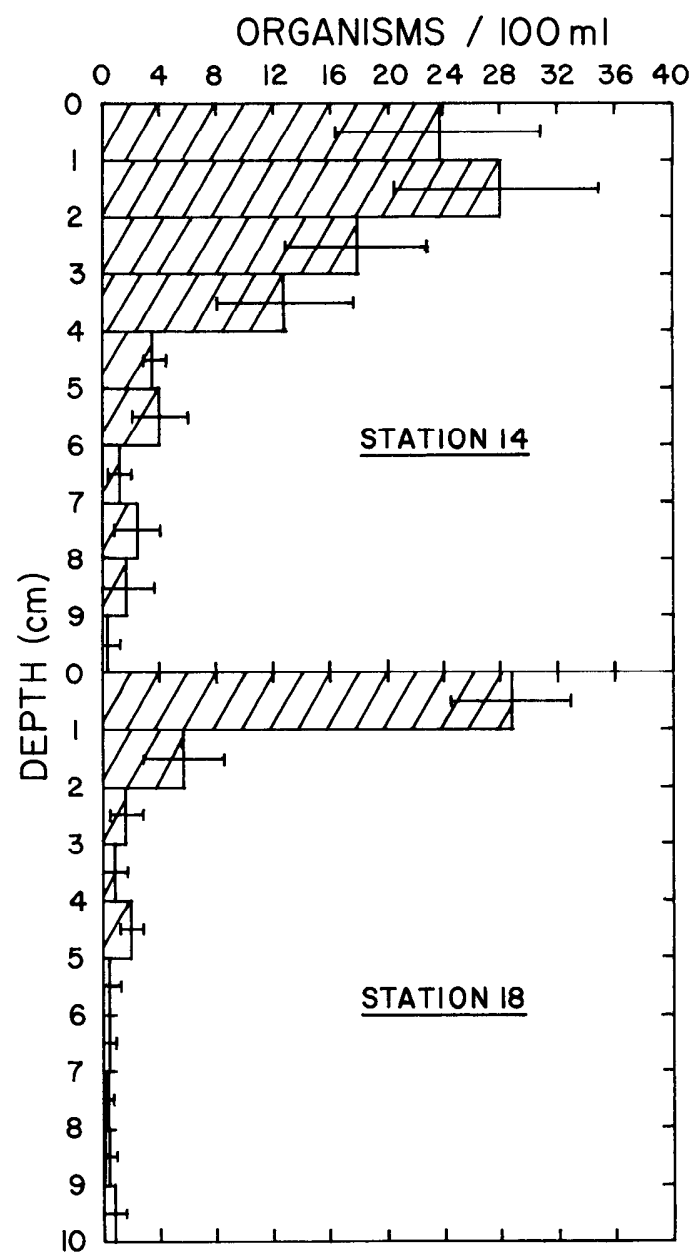

Fig. 1. Mean density of organisms in relation to depth in sediment, late August 1975. Error bars represent $95 \%$ confidence interval.

gray, sandy silt. Station 18, near the shoreward margin of the area of finegrained silt deposits, has firm, dark gray, sandy silt with flocculent material only in the uppermost $1 \mathrm{~cm}$. Porosity data are reported by Robbins et al. (1977). We assumed that the thicknesses of the mixed sediment layers were represented by the zones of constant ${ }^{210} \mathrm{~Pb}$ activity reported for these same two stations: $0-6 \mathrm{~cm}$ at station 14 and $0-3 \mathrm{~cm}$ at station 18 . The twelve cores taken at cach station were hydraulically extruded in a vertical position and sectioned in $1-\mathrm{cm}$ intervals to $10 \mathrm{~cm}$. The first four cores from each sta-
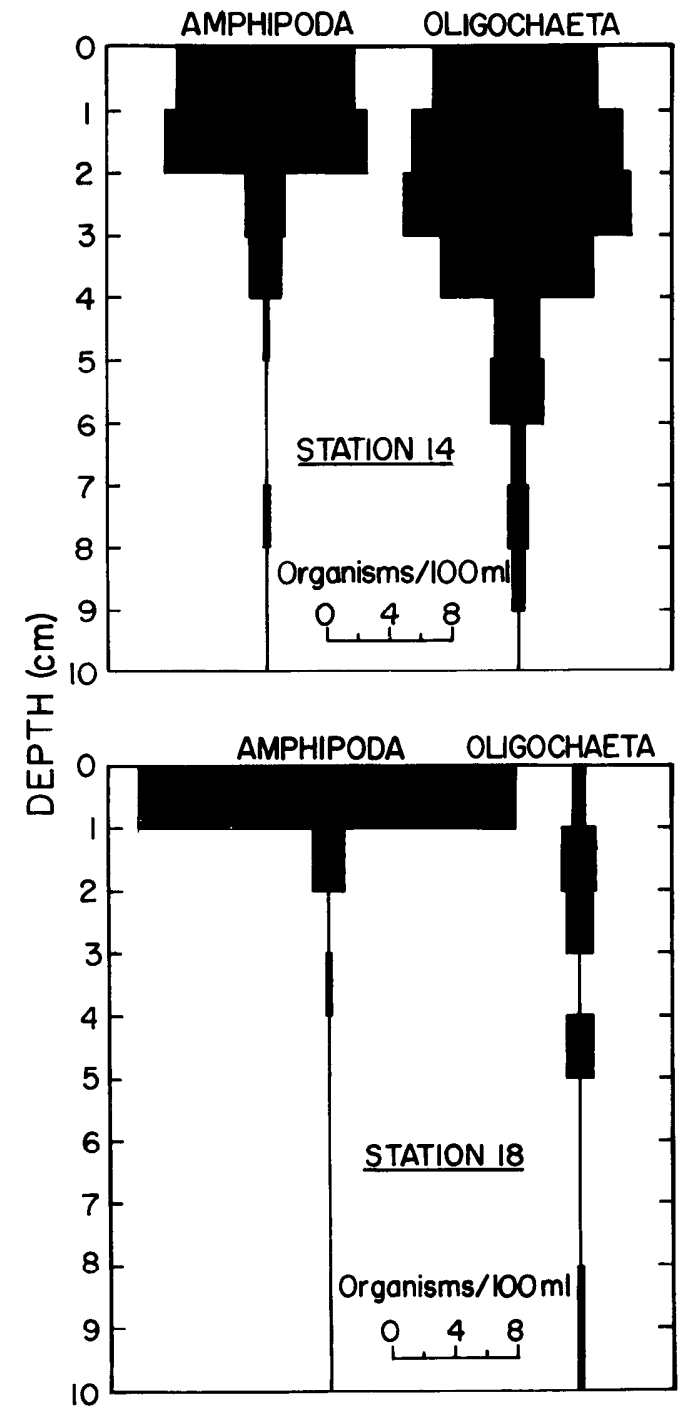

Fig. 2. Mean density of amphipods and oligochaetes in sediment.

tion were further sectioned in $5-\mathrm{cm}$ intervals to $20 \mathrm{~cm}$. All sectioning was completed within $30 \mathrm{~min}$ after the cores arrived on deck to limit, as much as possible, postsampling movements of the benthos and the sections were preserved with a buffered Formalin solution in Whirl-pak bags.

In the laboratory we suspended the samples in water, decanted the slurry through No. 10 mesh bolting cloth (openings $\approx 0.15 \mathrm{~mm}$ ), and sorted the organ- 
Table 1. Station parameters and taxonomic composition of macroinvertebrates in Lake Huron cores, August 1975.

\begin{tabular}{|c|c|c|}
\hline & Sta. 14 & Sta. 18 \\
\hline Location & $43^{\circ} 55^{\prime} \mathrm{N}, 82^{\circ} 07^{\prime} \mathrm{W}$ & $44^{\circ} 00^{\prime} \mathrm{N}, 81^{\circ} 59^{\prime} \mathrm{W}$ \\
\hline Water depth $(\mathrm{m})$ & 91 & 65 \\
\hline Amphipoda (Pontoporeia affinis) & $2,912 \pm 293 *(32)$ & $2,678 \pm 242(66)$ \\
\hline Diptera (Heterotrissocladius oliveri) & $48 \pm 32$ & $\begin{array}{ll}0 & (0)\end{array}$ \\
\hline Mysidacea (Mysis relicta) & $(0)$ & $48 \pm 32$ \\
\hline $\begin{array}{l}\text { Oligochaeta (Enchytraeidae, Limnodrilus } \\
\text { hoffmeisteri, Tubifex kessleri americanus, } \\
\text { T. tubifex, Vejdovskyella intermedia, } \\
\text { and unidentifiable immature Tubificidae) }\end{array}$ & $5,661 \pm 606 \quad(62)$ & $634 \pm 178(16)$ \\
\hline Pelecypoda (Pisidium) & $471 \pm 107$ & $705 \pm 153(17)$ \\
\hline Total & $9,092 \pm 713(100)$ & $4,065 \pm 304(100)$ \\
\hline
\end{tabular}

* Organisms $\cdot \mathrm{m}^{-2}$ (mean of 12 cores $\pm \mathrm{SE}$ ); percent of total station abundance in parentheses.

isms under $10 \times$ or greater magnification. Chironomidae and Oligochaeta were identified under a microscope, and only worm fragments with heads $(50-70 \%$ of the population) were included in the totals. Preserved amphipods were sorted into four size classes (I, $<3 \mathrm{~mm}$; II, 3-5 $\mathrm{mm}$; III, $5-7 \mathrm{~mm}$; IV $>7 \mathrm{~mm}$ ) and preserved whole tubificids into three (I, $<5$ $\mathrm{mm}$; II, 5-10 $\mathrm{mm}$; III, $>10 \mathrm{~mm}$ ).

The taxonomic composition of the larger benthic invertebrates (Table 1) was similar to that found in earlier studies of deeper areas of the Great Lakes (Cook and Johnson 1974), except for the absence of the oligochaete Stylodrilus. Amphipoda and Oligochaeta together comprised $94 \%$ of the individuals at station 14 and $82 \%$ at station 18 . Most of the remainder were Pisidium and these occurred principally in the upper $2 \mathrm{~cm}$. The total benthos density was greatest at station 14.

The stability of physical conditions at the depths of these stations would minimize tendencies for seasonal changes in amphipod and oligochaete abundance. Alley and Mozley (1975) found no seasonal variation for amphipods and oligochaetes in Lake Michigan. Chironomid larvae-the only animals which do vary seasonally-are at a minimum in late summer. The virtual absence of any larvae suggests that emergence of the adults was completc by latc August at our stations. The density of chironomids is generally low in deeper areas of the Great
Lakes (Alley and Mozley 1975), so that this seasonality is of minor importance here.

The index of precision (ratio of standard error to the mean: Flliott 1971) in Lake Huron for total benthic invertebrates integrated over depth was about $8 \%$, far better than the $20 \%$ we expected from a sample size of twelve cores per station. The sampling precision for individual strata was poor below $4 \mathrm{~cm}$, however, because of the very low numbers of animals there.

Previous reports of oligochaete density for stations near the present ones (e.g. Shrivastava 1974) rarely exceeded 450 worms $\cdot \mathrm{m}^{-2}$. We found 5,661 worms $\cdot \mathrm{m}^{-2}$ at station 14 and 634 at station 18, presumably because of our more effective sampling method and finer sieve mesh $(0.15 \mathrm{~mm})$. Bottom grab samplers, such as the Ponar sampler Shrivastava used, are generally less efficient than corers in capturing and retaining benthic organisms (Flannagan 1970). The $0.5-\mathrm{mm}$ sieve used by Shrivastava (1974) is almost $100 \%$ effective in retaining amphipods and Pisidium, but less so for other taxa (Mozley 1975). Differences in worm density between our study and Shrivastava's can be attributed to differences in sieve mesh size, although spatial inhomogeneity cannot be ruled out.

Of the organisms collected at station $14,87 \%$ were found within the $0-4-\mathrm{cm}$ interval, $62 \%$ of these above $2 \mathrm{~cm}$. At station $18,71 \%$ of the organisms were in the 


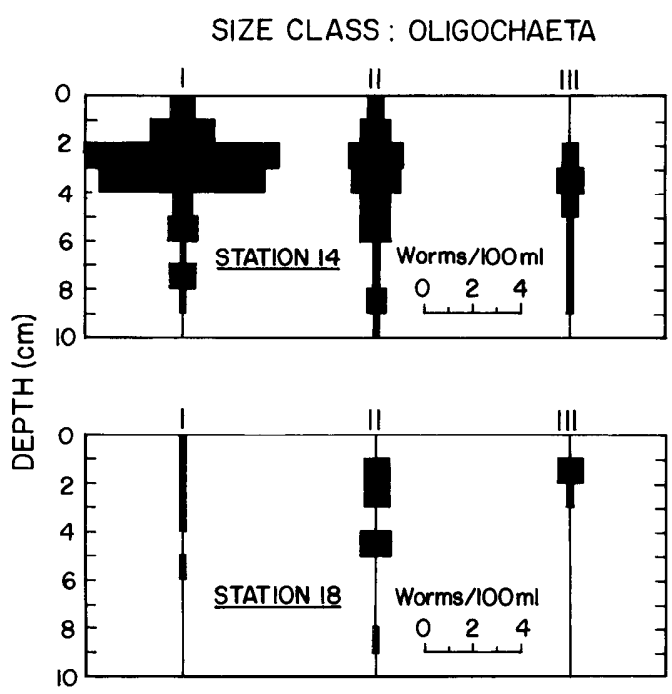

Fig. 3. Mean density of three size classes (preserved length) of oligochaetes in sediments $(\mathrm{I}=<5$ $\mathrm{mm} ; \mathrm{II}=5-10 \mathrm{~mm}$; III $=>10 \mathrm{~mm}$ ).

0-1-cm interval (Fig. 1). None were found below $10 \mathrm{~cm}$ at either station. Oneway ANOVA, performed for each station, verified that animal densities varied significantly with depth $(P<0.001)$ but pairwise contrasts (Tukey's T) of the mean densities of animals at each depth indicated that the densities within the 0 4 -cm interval at station 14 were not significantly different from one another $(P=$ $0.50)$. The densities below $4 \mathrm{~cm}$, however, were significantly smaller than above $4 \mathrm{~cm}(P<0.05)$. At station 18, densities of animals were significant in the $0-2$-cm interval $(P<0.05)$ but below 2 $\mathrm{cm}$ not significantly different from zero $(P=0.50)$. Amphipods inhabited the uppermost regions of the sediments $(0-4$ $\mathrm{cm}$ ) while the oligochaetes occurred deeper, to $\approx 6 \mathrm{~cm}$ (Fig. 2 ).

Densities of size classed oligochaetes differed significantly with depth in the sediment at station 14 for size classes I and II $(P<0.05)$ (Fig. 3); insufficient numbers in size class III at station 14 and in all size classes at station 18 precluded size vs. depth analysis at a suitable level of confidence $(P=0.25)$. While the greater numbers of smaller oligochaetes (size classes I and II) may represent a natural size distribution at station 14 , our data are insufficient to rule out seasonal effects. Our method of sectioning may have fragmented significant numbers of larger worms and resulted in improper size class groupings. Amphipods were distributed uniformly within the $0-2$-cm interval at station 14 for size classes I and II and their densities were significant only within this interval $(P<0.001)$ (Fig. 4); for size class III they were uniformly distributed to $4 \mathrm{~cm}$. None were found below this depth $(P<0.001)$. Densities of amphipods in size class IV at station 14 were not significantly different from zero $(P=$ 0.05 ). At station 18 , densities of amphipods in all size classes were significant only within the $0-1-\mathrm{cm}$ interval $(P<$ 0.001 ) (Fig. 4). From the variances found in our study, sample size calculations from Pearson-Hartley tables indicate a sample size of more than 20 cores per station would be needed for a significant study of amphipod size vs. depth distribution and more than 50 cores per station would be needed for a significant study of oligochaete size vs. depth distribution.

To determine whether the densities of animals found were sufficient to homogenize the near-surface sediments, we compared defecation rates calculated from Appleby and Brinkhurst's (1970) observations at $4^{\circ}-6^{\circ} \mathrm{C}$ to profundal Lake Huron sedimentation rates from Robbins et al. (1977). Hypothetically, complete homogenization of the upper sediments within the zone inhabited by the worms should occur when sediment displacement by the worms is comparable to or exceeds the sediment accumulation rate (Berger and Heath 1968). Although other species may contribute to sediment mixing, their egestion rates are unknown, and tubificids have been considered the important mixers of surface sediments (Alsterberg 1925; Davis 1974b). We assumed that the average annual bottom temperatures at stations 14 and 18 were $4^{\circ} \mathrm{C}$, that all oligochaetes observed defecated at the rate of Tubifex tubifex, that each worm averaged $0.43 \mathrm{mg}$ wet weight (our worms ranged from 0.2 to 2 $\mathrm{mg}$ wet $\mathrm{wt} \cdot \mathrm{worm}^{-1}$ ), and that 0.15 wet 
SIZE CLASS: AMPHIPODA
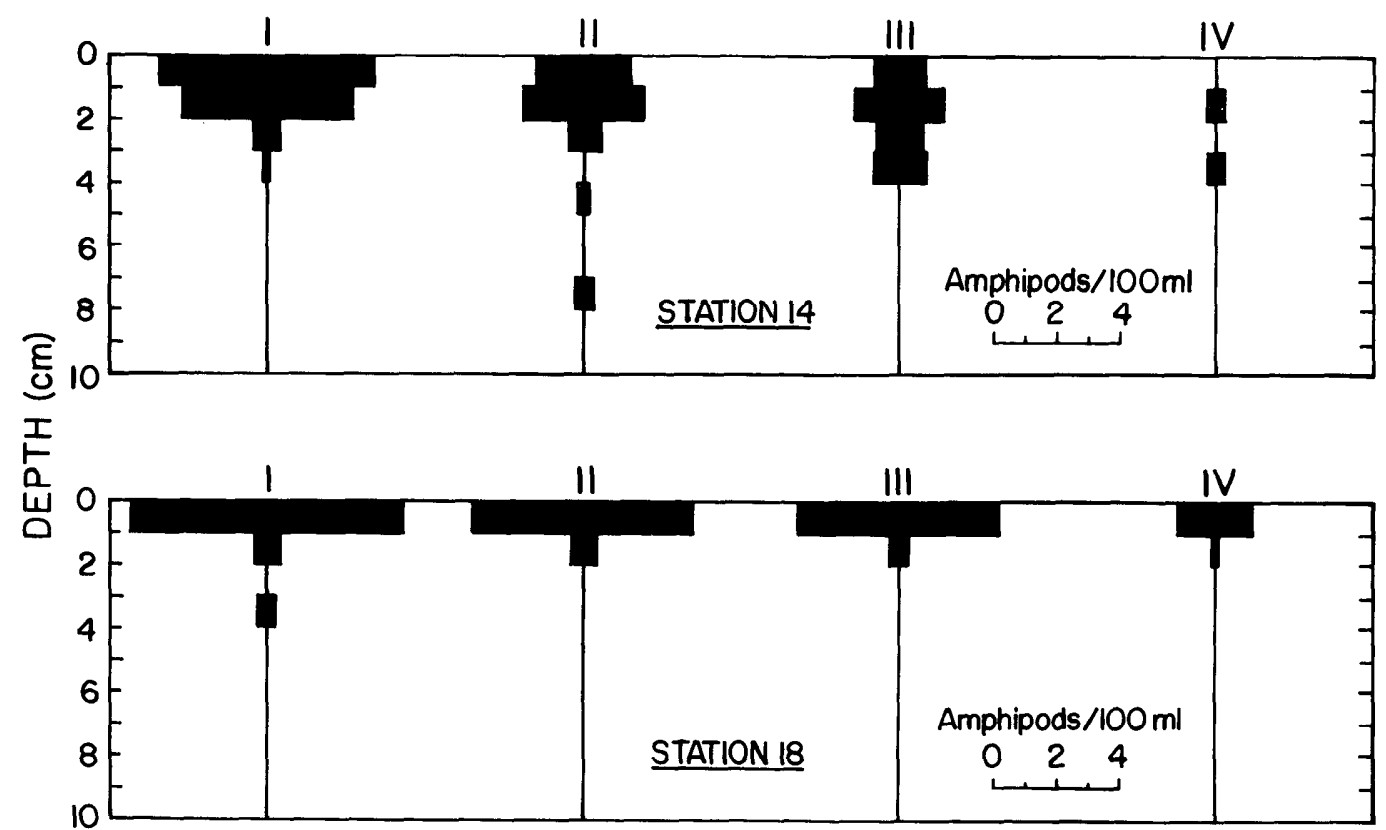

Fig. 4. Vertical distribution and mean density of four size (length) classes of amphipods ( $\mathrm{I}=<3 \mathrm{~mm}$; II $=3-5 \mathrm{~mm}$; III $=5-7 \mathrm{~mm} ; \mathrm{IV}=>7 \mathrm{~mm}$ ).

weight $=$ dry weight $($ Appleby and Brinkhurst 1970). With these assumptions, two of Appleby and Brinkhurst's experiments conform to the conditions we found in southern Lake Huron and suggest a range of defecation rate from 0.2 to $0.3 \mathrm{mg}$ dry wt sediment $\mathrm{mg}$ dry wt worm ${ }^{-1} \cdot \mathbf{h}^{-1}$. If we assume mean rate, $0.25 \mathrm{mg}$ dry wt sediment. $\mathrm{mg}$ dry wt worm $^{-1} \cdot \mathrm{h}^{-1}$ equals $2.2 \mathrm{~g}$ dry wt sediment.mg dry wt worm ${ }^{-1} \cdot \mathrm{yr}^{-1}$. Since the calculated mean dry weight per worm equals $0.065 \mathrm{mg}$ we estimate that each worm casts up $143 \mathrm{mg}$ dry weight of sediment each year. This calculation obviously overlooks the difference in sediment conditions between Toronto Harbour and profundal Lake Huron and assumes no seasonal change in biomass or reworking rate. We used sedimentation rates of 0.021 and $0.051 \mathrm{~g}$ dry wt sediment $\cdot \mathrm{cm}^{-2} \cdot \mathrm{yr}^{-1}$ at stations 14 and 18 (Robbins et al. 1977) to calculate the densities necessary to make worm mixing capacity (defecation rate) equal sedimentation rate. Densities $>1,470$ worms $\cdot \mathrm{m}^{-2}$ at station 14 and 3,570 worms $\cdot \mathrm{m}^{-2}$ at station 18 would be sufficient for mixing capacity to exceed sediment deposition.

Our data on worm density (Table 1) indicate that the sediment homogenization capacity of the worms at station 14 could exceed the sedimentation rate by a factor of four. The calculated worm mixing capacity was less than the sedimentation rate at station 18 , but this does not mean that the benthos were incapable of mixing the sediments there. First, the percentage of solids per volume of sediment was nearly double that at station 14 (Robbins et al. 1977) and the worms probably ingested the sediments according to volume rather than weight, moving more sediment than calculated. Second, the other animals at station 18, particularly the amphipods and Pisidium, may play a significant role in mixing there. Amphipods burrow randomly through the top 3 $\mathrm{cm}$ of sediment (Marzolf 1965; Milbrink 1973) and Pisidium, which normally lives a few millimeters below the sedimentwater interface, can extend its foot to at 
least $150 \%$ of its body length during translocation and can affect the sediment to $2.5 \mathrm{~cm}$ (P. L. McCall pers. comm.).

The greater thickness of the mixed layer of sediments at station 14 than at 18 is associated with a larger population of oligochaetes and deeper penetration of the benthos as a whole. Whether physical processes associated with sedimentation can reduce compaction of the sediments and consequently allow deeper burrowing of the benthos, or whether the mixed layer exists despite the presence of the benthos, remains unclear. But the parallels between the zoobenthos distributions and the depth of sediment mixing (Robbins et al. 1977), together with calculations of some of their mixing rates due to feeding activities, indicate that zoobenthos probably are important in mixing profundal sediments. The effects of bioturbation should therefore be considered in geochemical studies and in the reconstruction of postsettlement records from recent sediments of the Great Lakes. We thank R. B. Davis and P. L. McCall for their reviews and comments.

\section{John R. Krezoski Samuel C. Mozley John A. Robbins}

Great Lakes Research Division

University of Michigan

Ann Arbor 48109

\section{References}

Alley, W. P., And S. C. Mozley. 1975. Seasonal abundance and spatial distribution of Lake Michigan macrobenthos, 1964-1967. Univ. Mich. Great Lakes Res. Div. Spec. Rep. 54. $103 \mathrm{p}$.

ALSTERBEkG, G. 1925. Nahrungszirkulation einiger Binnenseetypen. Arch. Hydrobiol. 15: 291-338.

ApPleby, A. G., AND R. O. Brinkhurst. 1970. Defecation rate of three tubificid oligochaetes in the sediment of Toronto Harbour, Ontario. J. Fish. Res. Bd. Can. 27: 1971-1982.

Berger, W. H., AND G. R. HeAth. 1968. Vertical mixing in pelagic sediments. J. Mar. Res. 26: $134-143$.
Brinkhurst, R. O., K. E. Chua, and E. BatoosINGH. 1969. Modifications in sampling procedures as applied to studies on the bacteria and tubificid oligochaetes inhabiting aquatic sediments. J. Fish. Res. Bd. Can. 26: 2581-2593.

Cook, D. G., And M. G. Johnson. 1974. Benthic macroinvertebrates of the St. Lawrence Great Lakes. J. Fish. Res. Bd. Can. 31: 763-782.

Davis, R. B. 1967. Pollen studies of near-surface sediments in Maine lakes, p. 153-175. In E. J. Cushing and H. E. Wright [eds.], Quaternary palcoccology. Yale Univ.

— 1974a. Tubificids alter profiles of redox potentials and pHI in profundal lake sediment. Limnol. Oceanogr. 19: 342-345.

- $1974 b$. Stratigraphic effects of tubificids in profundal lake sediments. Limnol. Oceanogr. 19: $466-488$.

ElliotT, J. M. 1971. Some methods for the statistical analysis of samples of benthic invertebrates. Freshwater Biol. Assoc. Sci. Publ. 25. $144 \mathrm{p}$.

Flannagan, J. F. 1970. Efficiencies of various grabs and corers in sampling freshwater benthos. J. Fish. Res. Bd. Can. 27: 1691-1700.

Marzolf, G. R. 1965. Substrate relations of the burrowing amphipod Pontoporeia affinis in Lake Michigan. Ecology 46: 579-592.

Milbrink, G. 1973. On the vertical distribution of oligochaetes in lake sediments. Rep. Inst. Freshwater Res. Drottningholm 53: 34-50.

Mozley, S. C. 1975. Preoperational investigations of zoobenthos in southeastern Lake Michigan near the Cook Nuclear Plant. Univ. Mich. Great I akes Res. Div. Spec. Rep. 56. 132 p.

RHOADS, D. C. 1963. Rates of sediment reworking by Yoldia limatula in Buzzards Bay, Massachusetts and Long Island Sound. J. Sediment. Petrol. 33: 723-727.

- 1974. Organism-sediment relations on the muddy sca floor. Occanogr. Mar. Biol. Annu. Rev. 12: 263-300.

Robbins, J. A., ANd D. N. Edgington. 1975. Determination of recent sedimentation rates in Lake Michigan using Pb-210 and Cs-137. Geochim. Cosmochim. Acta 39: 285-304. - J. R. Krezoski and S. C. Mozley. 1977. Radioactivity in sediments of the Great Lakes: Post-depositional redistribution by depositfeeding organisms. Earth Planet. Sci. Lett. 36: 325-333.

Shrivastava, H. 1974. Macrobenthos of Lake Huron. Fish. Res. Bd. Can. Tech. Rep. 449. 45 p.

Thomas, R. L., A. L. KEMP, AND C. F. LEWIs. 1973. Surficial sediments of Lake Huron. Can. J. Earth Sci. 10: 226-271.

Submitted: 3 December 1976 Accepted: 21 February 1978 